Article

\title{
The Selectivity of Different Sized Catalysts on DOM Fractional Removal during the Catalytic Ozonation of Municipal Sewage
}

\author{
Cheng Wang, Ji Wu, Aimin $\mathrm{Li}^{*}$ and Chendong Shuang * \\ State Key Laboratory of Pollution Control and Resource Reuse, School of the Environment, Nanjing University, \\ Nanjing 210023, China; yz_wc19890901@163.com (C.W.); wu1363516334@163.com (J.W.) \\ * Correspondence: liaimin@nju.edu.cn (A.L.); shuangchendong@nju.edu.cn (C.S.); Tel.: +86-25-8968-0377 (A.L.)
}

Received: 29 November 2018; Accepted: 21 December 2018; Published: 26 December 2018

\begin{abstract}
Dissolved organic matter (DOM) is a typical kind of pollutant with a complex composition, and different advanced treatments demonstrate different abilities toward its fractional removal. Hence, it is necessary to analyze the fraction of DOM that remains when using advanced treatments. In this paper, ozonation was used to deal with the biological effluents and comparisons of the catalytic ozonation with different particle sizes of $\gamma-\mathrm{Al}_{2} \mathrm{O}_{3}$ were made. The results of these comparisons indicated that the catalysts were active in improving the removal of DOM and $\gamma-\mathrm{Al}_{2} \mathrm{O}_{3}$ with different particle sizes can selectively remove DOM. The result of fluorescence showed that a decrease in the catalyst particle size contributes to a significant decrease in the fluorescence intensity, except for tryptophan-like substances. Meanwhile, DOM fractions with large molecular weights could be decomposed into small molecules by ozonation, resulting in increased hydrophilicity. However, the use of a catalyst in ozonation increased the removal of hydrophilic components. Additionally, a smaller catalyst particle size increased the removal of hydrophilic components. The results of catalyst analysis implied that the surface hydroxyl groups of catalyst $\gamma-\mathrm{Al}_{2} \mathrm{O}_{3}$ and the diffusion of DOM in the catalyst $\gamma-\mathrm{Al}_{2} \mathrm{O}_{3}$ played important roles in the ozonation catalytic process for the removal of DOM.
\end{abstract}

Keywords: dissolved organic matter; ozonation; advanced treatment; catalyst; particle size

\section{Introduction}

In the past few decades, the problem of water pollution has received increasing attention around the world [1]. As a great amount of wastewater is discharged into the environment, the municipal sewage needs to be treated with advanced treatment methods because conventional biological methods could not remove all the pollutants [2]. Dissolved organic matter (DOM) in the biological effluents are typical kind of pollutants with complex compositions [3], some of which cause threats to both human health and aquatic ecosystems because of problems such as bacteria reproduction [4] and disinfection by-products (DBPs) formation [5]. These DOMs are generally refractory since the conventional biological methods, coagulation and adsorption are ineffective due to its non-biodegradability, higher hydrophilicity, and lower molecular weight [6]. Therefore, many methods have recently been implemented in advanced treatment, such as reverse osmosis [7], nanofiltration [8], ion exchange [9], advanced oxidation processes (AOPs) [10], and an integrated process [11].

Ozone oxidation, as one of the advanced treatment methods, has been widely applied in municipal sewage treatment because it is easy to perform [12]. It has been proven to be effective in processing trace poisonous, harmful chemicals and refractory organic compounds by direct oxidation with $\mathrm{O}_{3}$ or indirectly, via reaction with hydroxyl radical $[13,14]$. Some approaches or conditions were optimized 
to enhance hydroxyl radical generation because the hydroxyl radical is more effective than $\mathrm{O}_{3}$ for oxidation [15]. Therefore, the catalyst is frequently used in ozone oxidation as it increases the generation of hydroxyl radicals [16-19]. At present, the development and application of noble metal catalysts are interesting for research [20-22]. The noble metals are usually loaded onto supports including metal oxide and activated carbon for preventing their loss [23,24]. However, these catalysts are generally more expensive than the metal oxide typically used for industrial applications on water treatment.

To date, there have been some studies regarding the removal of different DOM by ozone oxidation. Gong separated the DOM into four fractions through hydrophobicity/hydrophilicity analysis and found ozone reacted sequentially with aromatic hydrophobic components, transphilic components, and then, hydrophilic components; however, under UV (ultraviolet rays), it reacted with all four organic fractions simultaneously. Low-MW (molecular weight) hydrophilic components were the most abundant fraction in the ozone-treated effluent [25]. The use of a catalyst can generally increase the rate of the generation of hydroxyl radicals and improve the efficiency of ozone oxidation so that the removal rate of many matters is enhanced, such as phenolic [26] and halocarbons [27]. However, little research has been conducted on the fractional changes of DOM caused by a typical metal oxide with ozonation and particularly, the influence of catalyst sizes on DOM. In fact, information on the structural changes of DOM is important for the interpretation of the influence of catalytic ozonation on the potential formation of other intermediate products originating from the DOM [28]. It hindered the application and evaluation of catalytic ozonation technology for DOM removal.

In the present work, the common catalyst $\gamma-\mathrm{Al}_{2} \mathrm{O}_{3}$ was used for DOM removal under conditions suitable for industrial ozonation processes. The effect of the $\gamma-\mathrm{Al}_{2} \mathrm{O}_{3}$ particle size on the catalytic performance of municipal sewage was investigated by COD (chemical oxygen demand, a chemical method is used to measure the amount of reducing substances to be oxidized in a water sample, and reflects the degree to which water is polluted by reducing substances) and $\mathrm{UV}_{254}$. The DOM in treated water samples were further analyzed with three-dimensional fluorescence, gel permeation chromatography (GPC), and hydrophobicity/hydrophilicity. In addition, the acute toxicity of the treated solutions was evaluated to understand the potential risks to the environment.

\section{Results and Discussion}

\subsection{EEM (Excitation-Emission-Matrix Spectra) Analysis}

Three-dimensional fluorescence spectra for water quality determination can reveal the classification and information content of organic pollutants, and it also can be used on multiple complex systems with overlapping fluorescence spectra for the identification and characterization of an individual object spectrum [29]. The results showed that the secondary effluent may produce in several characteristic fluorescence peaks [29]: (1) the $\lambda_{\mathrm{Ex}}=300-370 \mathrm{~nm}, \lambda_{\mathrm{Em}}=400-500 \mathrm{~nm}$, the characteristic peak for the humic acid material (T4); (2) $\lambda_{\mathrm{Ex}}=237-260 \mathrm{~nm}, \lambda_{\mathrm{Em}}=400-500 \mathrm{~nm}$, fulvic-acid material characteristic peak (T3); (3) $\lambda_{\mathrm{Ex}}=235-240 \mathrm{~nm}, \lambda_{\mathrm{Em}}=340-355 \mathrm{~nm}$ and $\lambda_{\mathrm{Ex}}=280-285 \mathrm{~nm}$, $\lambda_{\mathrm{Em}}=320-335 \mathrm{~nm}$, for the characteristic peaks of the protein materials (T1, T2), including $\mathrm{T} 1$ for tyrosine and T2 for tryptophan. In the three-dimensional fluorescence spectra, shown in Figures 1 and 2, the fluorescence types can be divided into four parts; tyrosine, tryptophan, fulvic acid, and humic acid. T1, T2, T3, and T4, respectively, represent the maximum fluorescence intensity of these four different types of substances, namely tyrosine, tryptophan, fulvic acid, and humic acid. Figures 3 and 4 represent the changes in the maximum fluorescence intensity of these four substances under ozone and ozone-catalytic conditions, thus obtaining the degradation efficiency of ozone and ozone-catalytic fluorescence substances. T1 represents the change in tyrosine, T2 represents the change in tryptophan, $\mathrm{T} 3$ represents the change in fulvic acid, and $\mathrm{T} 4$ represents the change in humic acid.

The EEM spectra of the DOM fractions before and after ozonation and catalytic ozonation are shown in Figures 1 and 2. The intensities and positions of the EEM peaks after ozonation and catalytic ozonation were summarized in Figure 3. Results showed that ozonation decreases the intensities of 
fluorescence for all examined DOM fractions. After the addition of different particle size of $\gamma-\mathrm{Al}_{2} \mathrm{O}_{3}$, the intensities of fluorescence of T1, T2, T3, and T4 were further decreased. For sample A, on the one hand, the fluorescence intensities of $\mathrm{T} 1, \mathrm{~T} 3$, and $\mathrm{T} 4$ decreased with the decrease of the $\gamma-\mathrm{Al}_{2} \mathrm{O}_{3}$ particle sizes. On the other hand, the intensity of the fluorescence of T3 did not change significantly with a decrease of the particle size. For sample B, the fluorescence intensities of all the fluorescent components decreased with a decreasing particle size of the catalyst. Meanwhile, it could be found that the change of T3 was far less than other fractions. Thus, it could be concluded: (1) ozonation substantially reduces the intensities of the fluorescence of the examined DOM fractions by EEM; (2) the intensities were further reduced with the presence of the $\gamma-\mathrm{Al}_{2} \mathrm{O}_{3} ;(3)$ the decrease of the catalyst particle sizes contributed to the significant decrease of the fluorescence intensity, except for in tryptophan.
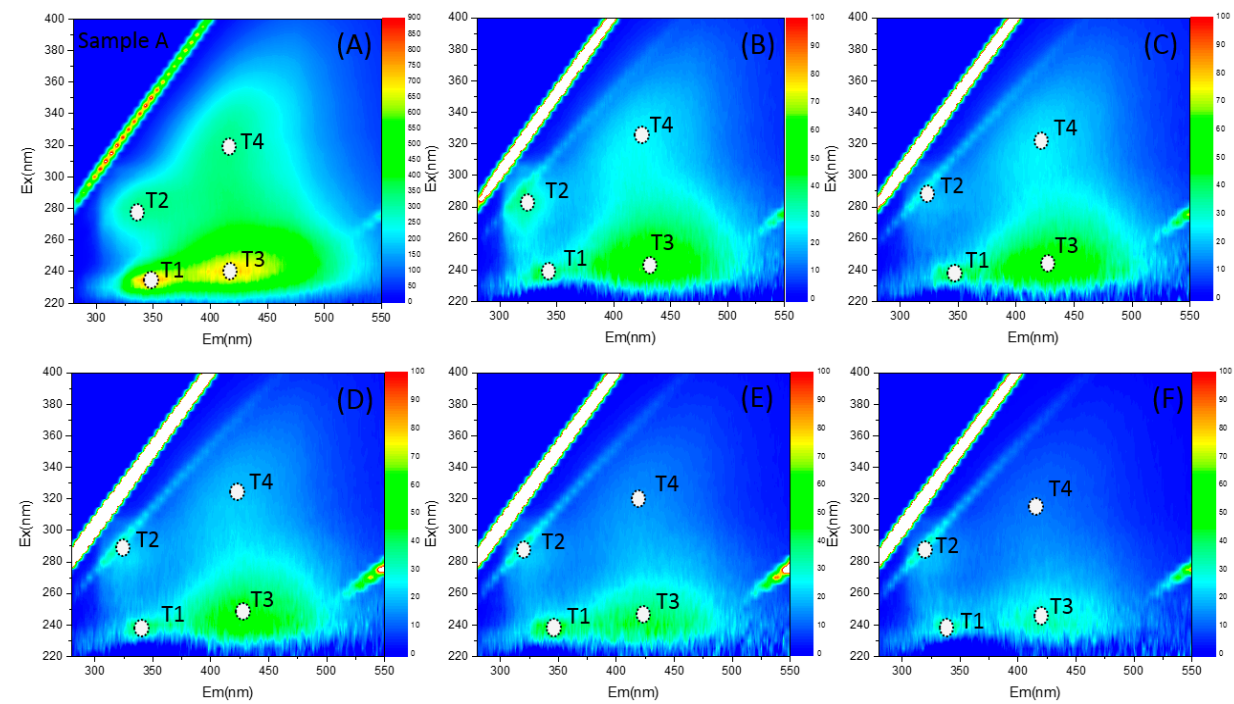

Figure 1. EEM spectra of sample A before (A) and after ozonation (B), catalytic ozonation by the catalysts (C-F) with fluorescence regions and peak maxima indicated for humic-like substances (Ex: 300-370 nm, Em: 400-500 nm), fulvic-like substances (Ex: 237-260 nm, Em: 400-500 nm) and protein-like structures (Ex: 235-240 nm, Em: 340-355 nm; Ex: 280-285 nm, Em: 320-335 nm).
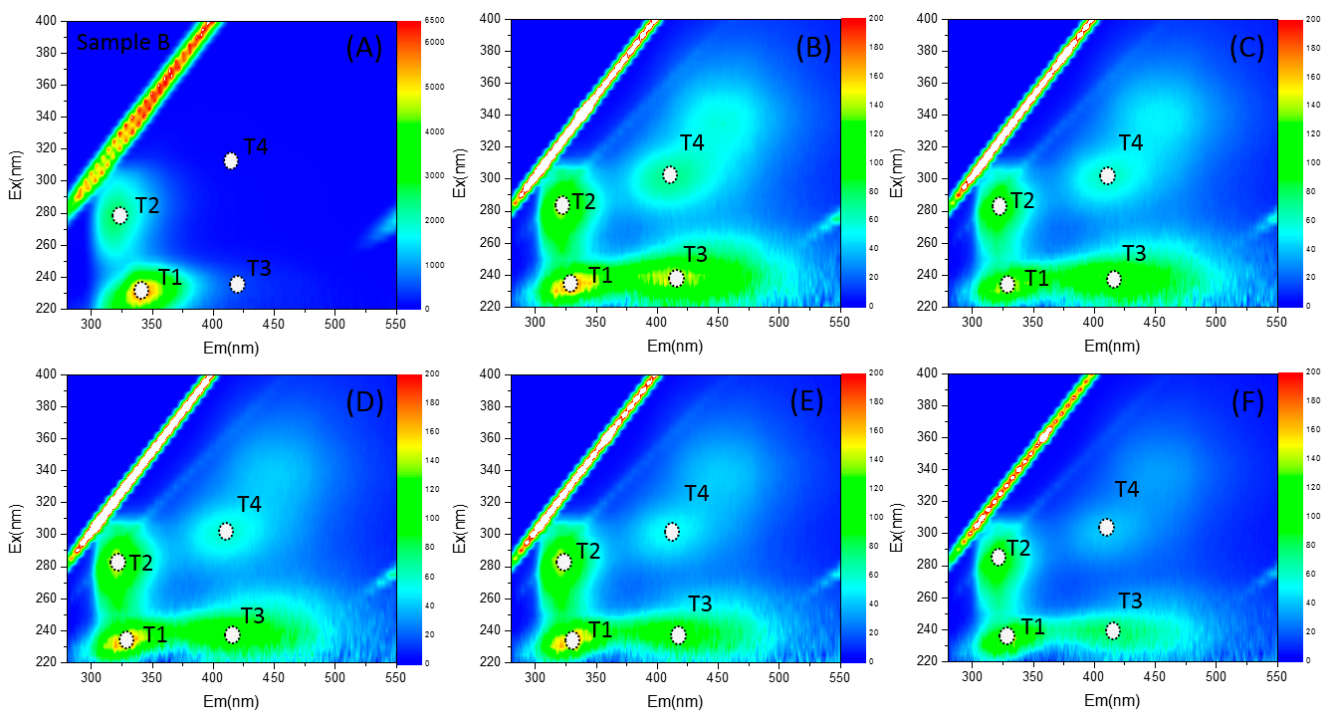

Figure 2. EEM spectra of sample B before (A) and after ozonation (B), catalytic ozonation by the catalysts (C-F) with fluorescence regions and peak maxima indicated for humic-like substances (Ex: 300-370 nm, Em: 400-500 nm), fulvic-like substances (Ex: 237-260 nm, Em: 400-500 nm) and protein-like structures (Ex: 235-240 nm, Em: 340-355 nm; Ex: 280-285 nm, Em: 320-335 nm). 

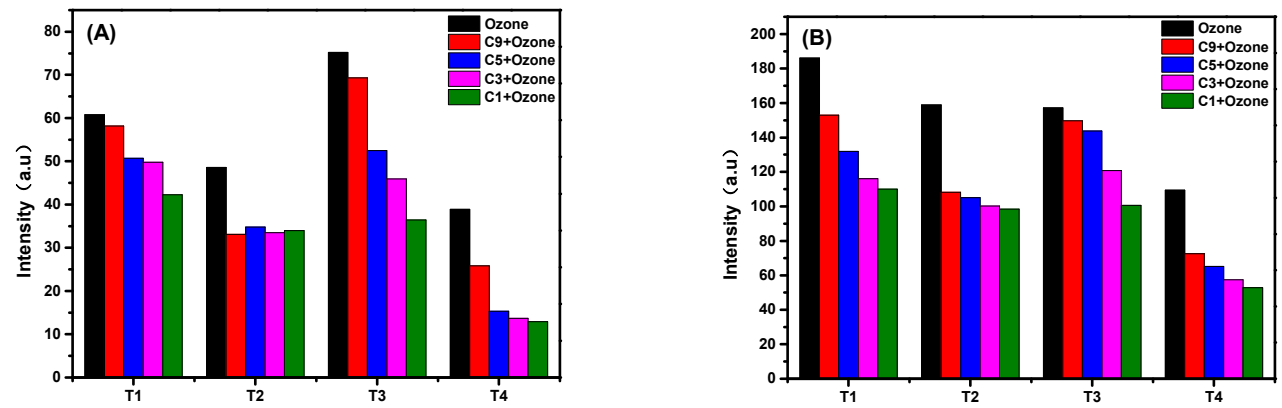

Figure 3. Intensities and positions of the EEM peak maxima after ozonation and catalytic ozonation. (sample A: (A), sample B: (B)), commercial $\gamma-\mathrm{Al}_{2} \mathrm{O}_{3}$ was mechanically broken into different particle sizes, and the particles were passed through screen mesh with different pore sizes so that they were divided into sizes of approximately $0.9 \mathrm{~mm}, 0.5 \mathrm{~mm}, 0.3 \mathrm{~mm}$ and $0.1 \mathrm{~mm}$, which were named C9, C5, C3, and C1, respectively.
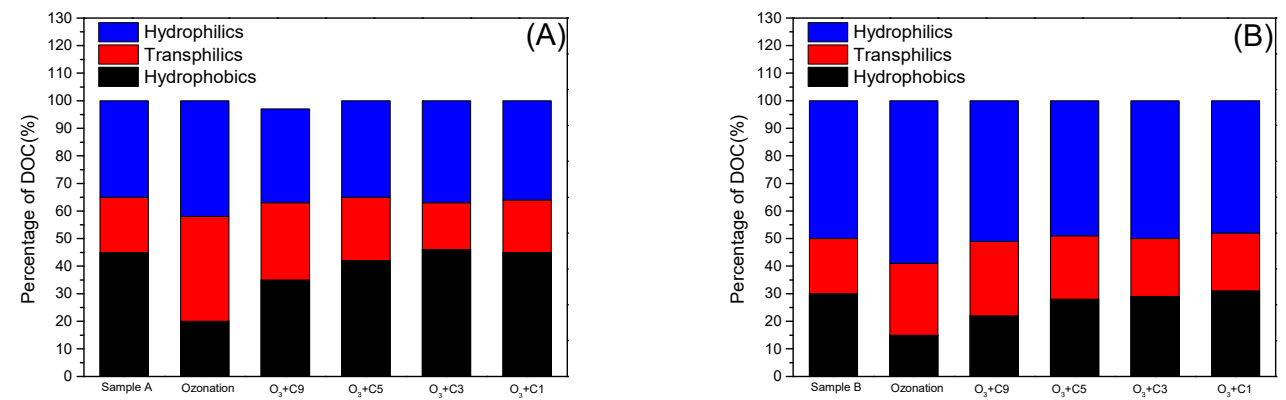

Figure 4. The proportions of hydrophilic/hydrophobic components in dissolved organic matter of sample A (A) and sample B (B).

\subsection{Effect of Hydrophobics/Hydrophilics by $\mathrm{O}_{3}$ and $\gamma-\mathrm{Al}_{2} \mathrm{O}_{3}$}

DOM in biotreated effluent with treatment by $\mathrm{O}_{3}$ and different sizes of $\gamma-\mathrm{Al}_{2} \mathrm{O}_{3} / \mathrm{O}_{3}$ were fractionated into hydrophobic components, transphilic components, and hydrophilic components by the XAD-4/XAD-8 resin. As can be seen from Figure 4, for sample A, hydrophobic components were the largest (about $45 \%$ ), followed by hydrophilic components (about $35 \%$ ), while transphilic components were in the smallest proportion (about $20 \%$ ). For sample B, the majority were hydrophilic components (about 50\%), then hydrophobic components (about $30 \%$ ), and transphilic components (about 20\%). Hydrophobic components were mainly aromatic substances and aliphatic substances, hydrophilic components were mainly divided into substances such as polysaccharides, amino acids, and microorganism metabolites [30]. When under the condition of ozone alone, the hydrophobic components decreased significantly from $45 \%$ to $20 \%$ for sample A and from $50 \%$ to $15 \%$ for sample $\mathrm{B}$, respectively. This result indicates that ozone was selective and preferred to remove hydrophobic components in municipal sewage. Similar reports were also reported in other literature $[25,28]$. However, in the presence of $\gamma-\mathrm{Al}_{2} \mathrm{O}_{3}$, the proportion of hydrophobic components was gradually increased with a decreasing catalyst particle size, which means that this selectivity of the removal by ozone had begun to decline. From the experimental results, one could speculate that by adding $\gamma-\mathrm{Al}_{2} \mathrm{O}_{3}$ in the water the number of hydroxyl radicals produced gradually increased with the decrease of the catalyst particle sizes. The hydroxyl radicals were non-selective [31,32]. Thus, the hydroxyl radicals was effective for removing each component. Because the small particle size of $\gamma-\mathrm{Al}_{2} \mathrm{O}_{3}$ could produce more hydroxyl radicals, the small particle of $\gamma-\mathrm{Al}_{2} \mathrm{O}_{3}$ could more effectively remove hydrophilic components in the catalytic ozonation system. 


\subsection{The Change of Different MW Organic Matter by $\mathrm{O}_{3}$ and $\gamma-\mathrm{Al}_{2} \mathrm{O}_{3} / \mathrm{O}_{3}$}

The molecular weight distribution of the wastewater has been studied by GPC (gel permeation chromatography). Figure 5 showed the molecular weight distribution of the wastewater after ozonation or $\gamma-\mathrm{Al}_{2} \mathrm{O}_{3} / \mathrm{O}_{3}$. For sample $\mathrm{A}$, see Figure $5 \mathrm{~A}$, there were two obvious peaks in untreated water, whose corresponding Mw values were 9417 and $2292 \mathrm{Da}$, respectively. Distinct changes occur in the molecular weight distribution curve with ozonation; the intensity of the two peaks rapidly decreased. The $\mathrm{Mw}$ (2292 Da) could not be obtained as a result. Then, with $\gamma-\mathrm{Al}_{2} \mathrm{O}_{3} / \mathrm{O}_{3}$, the intensity of $\mathrm{Mw}$ (9417 Da) reduced more significantly, which means that with the addition of the catalyst, more substances at this molecular weight were degraded or decomposed into smaller molecular weight substances and they were, therefore, difficult to detect by GPC. Meanwhile, with the decrease of the particle size of $\gamma-\mathrm{Al}_{2} \mathrm{O}_{3}$, the change was more obvious. For sample B, a similar situation had occurred, see Figure 5B. Compared to the previous degradation rate of $\mathrm{COD}$, it could be found that ozone could effectively oxidize the macromolecular substances into small molecules in wastewater. However, this oxidation was not complete and there were still many small molecules in the wastewater. With the addition of the $\gamma-\mathrm{Al}_{2} \mathrm{O}_{3}$, the decomposition rate of the macromolecular substances could not only be improved, but also the substances which were difficult to mineralize completely with ozone could be removed. What's more, with the decrease of the particle sizes of $\gamma-\mathrm{Al}_{2} \mathrm{O}_{3}$, the mineralization rate will be significantly improved.
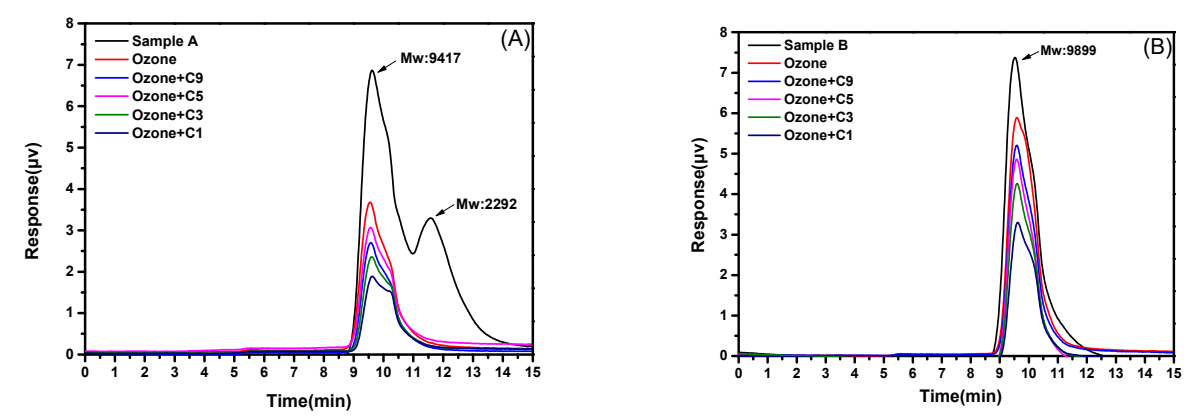

Figure 5. Molecular weight distribution of sample A (A) and sample B (B) before and after ozonation and catalytic ozonation measured at $\lambda=254 \mathrm{~nm}$.

\subsection{Removal of DOM and Kinetics}

This study selected two different kinds of typical domestic sewage, and the COD of the effluent was similar. The water quality was analyzed and discussed by the same ozonation and ozonation catalytic process. The removal of the organic fractions of the biotreated sample was monitored during the treatment with $\mathrm{O}_{3}$ and different sizes of $\gamma-\mathrm{Al}_{2} \mathrm{O}_{3} / \mathrm{O}_{3}$. The results are shown in Figure 6 (sample A) and Figure 7 (sample B). Figures $6 \mathrm{~A}$ and $7 \mathrm{~A}$ show that $\mathrm{UV}_{254}$ declined quickly following treatment with $\mathrm{O}_{3}$ or $\gamma-\mathrm{Al}_{2} \mathrm{O}_{3} / \mathrm{O}_{3}$ during the first $3 \mathrm{~min}$. For sample $\mathrm{A}$, the degradation rate of $\mathrm{UV}_{254}$ was $60 \%$, $62 \%, 65 \%, 70 \%$, and $75 \%$ by $\mathrm{O}_{3}, \mathrm{C} 9 / \mathrm{O}_{3}, \mathrm{C} 5 / \mathrm{O}_{3}, \mathrm{C} 3 / \mathrm{O}_{3}$, and $\mathrm{C} 1 / \mathrm{O}_{3}$, respectively. After $3 \mathrm{~min}$, there was almost no obvious change. For sample $\mathrm{B}$, the degradation rate of $\mathrm{UV}_{254}$ was $50 \%, 55 \%, 56 \%, 60 \%$, and $65 \%$ by $\mathrm{O}_{3}, \mathrm{C} 9 / \mathrm{O}_{3}, \mathrm{C} 5 / \mathrm{O}_{3}, \mathrm{C} 3 / \mathrm{O}_{3}$, and $\mathrm{C} 1 / \mathrm{O}_{3}$, respectively. Then, the decline rate slowed down notably, achieving an overall reduction of $62 \%, 65 \%, 68 \%, 74 \%$, and $78 \%$ by $\mathrm{O}_{3}, \mathrm{C} / \mathrm{O}_{3}, \mathrm{C} 5 / \mathrm{O}_{3}, \mathrm{C} 3 / \mathrm{O}_{3}$, and $\mathrm{C} 1 / \mathrm{O}_{3}$, respectively, at the end of $6 \mathrm{~min}$. Results indicate that ozonation was quite effective in the destruction of aromatic and double bond systems, as indicated by $\mathrm{UV}_{254}$. However, for the COD of the samples, ozonation was relatively ineffective in the mineralization. The degradation rate of COD was only $20 \%$ and $25 \%$ for sample A and B, respectively, by ozonation. When adding the different particle sizes of $\gamma-\mathrm{Al}_{2} \mathrm{O}_{3}$, the degradation rate was significantly improved, reaching $32 \%, 36 \%, 42 \%$, and $49 \%$, respectively (sample A). Likewise, for sample B, the degradation rate reached $35 \%, 38 \%$, $43 \%$, and $48 \%$, respectively. This indicated that the catalysts were active in improving the ozonation of DOM and the catalytic activity was enhanced with the decrease of the particle size of the catalyst. 
SUVA (specific ultraviolet absorbance, it is the ratio of $\mathrm{UV}_{254}$ to dissolved-organic-carbon, which can indirectly represent the hydrophilic and hydrophobic characteristics of organic compounds in water) was commonly used to characterize the aromatic content of organic matter. The higher the SUVA, the stronger the aromatic character of the organics. Ozonation treatments led to a significant SUVA reduction (i.e., from 2.03 to $1.03 \mathrm{~L} / \mathrm{m} / \mathrm{mg}$ and 1.59 to $0.80 \mathrm{~L} / \mathrm{m} / \mathrm{mg}$ for sample $\mathrm{A}$ and B, respectively). Then, under the condition of ozone, the SUVA was further decreased. Additionally, with the decrease of the particle size of the catalyst, SUVA gradually decreased (i.e., from 1.02 to $0.82 \mathrm{~L} / \mathrm{m} / \mathrm{mg}$ and 0.75 to $0.64 \mathrm{~L} / \mathrm{m} / \mathrm{mg}$ for sample $\mathrm{A}$ and $\mathrm{B}$, respectively). Ozone was known to preferentially react with unsaturated organic structures by breaking down double bonds so that the aromatic character of the organics decreased. However, the removal of DOM by ozone alone was not obvious. When added to the catalyst, the ability of ozone to remove aromatic organics increases and it can also effectively remove DOM.
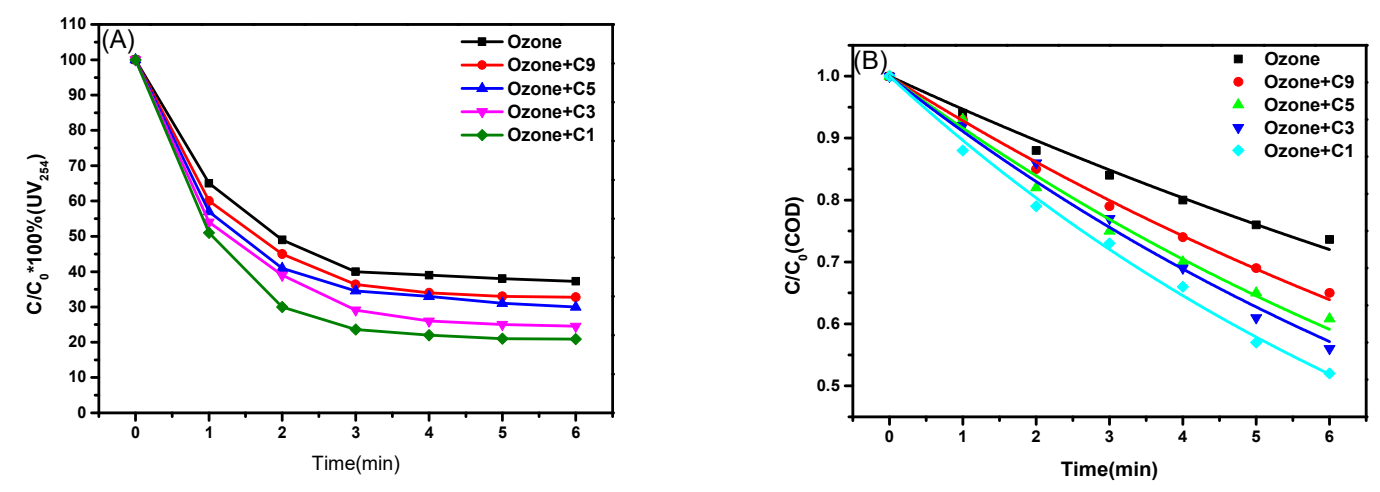

Figure 6. The removal of $\mathrm{UV}_{254}(\mathrm{~A})$ and $\mathrm{COD}(\mathbf{B})$ for the sample A during treatment by $\mathrm{O}_{3}$ and different size of $\gamma-\mathrm{Al}_{2} \mathrm{O}_{3} / \mathrm{O}_{3}$.
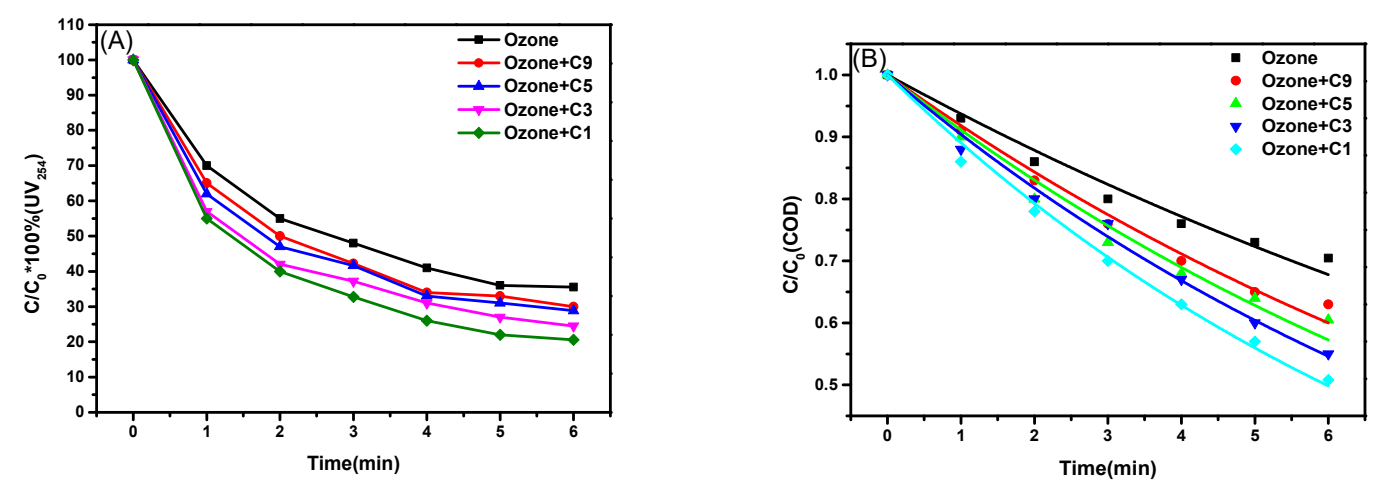

Figure 7. The removal of $\mathrm{UV}_{254}$ (A) and chemical oxygen demand (COD) (B) for the sample B during treatment by $\mathrm{O}_{3}$ and different size of $\gamma-\mathrm{Al}_{2} \mathrm{O}_{3} / \mathrm{O}_{3}$.

In order to further elucidate the removal of DOM caused by different particle sizes of the catalyst during the catalytic process, the characteristics of the catalyst were also studied, including BET (Brunauer-Emmett-Teller), concentration of surface hydroxyl groups, and $\mathrm{pH}_{\mathrm{pzc}}$. Specific values were shown in Table 1. The BET surface area of $\gamma-\mathrm{Al}_{2} \mathrm{O}_{3}$ with different particle sizes was approximately between 302 and $322\left(\mathrm{~m}^{2} \cdot \mathrm{g}^{-1}\right)$; it didn't show a big difference among them. Therefore, a large particle size of $\gamma-\mathrm{Al}_{2} \mathrm{O}_{3}$ may have more pores, resulting in no significant difference in the BET surface area compared with small particle sizes. One factor regarding the difference of the activity between different particle sizes of $\gamma-\mathrm{Al}_{2} \mathrm{O}_{3}$ was that the small particle catalyst had a greater chance of collision with pollutant and ozone in the reaction process. On the other hand, the surface hydroxyl of the catalyst was an important aspect of the surface characteristic of the catalyst, and it was considered that it had played a vital role in the heterogeneous catalytic ozonation engineering [33]. When introduced into water, 
metal oxides strongly adsorb $\mathrm{H}_{2} \mathrm{O}$ molecules to form surface hydroxyl groups [34]. The hydroxyl groups formed on the metal oxide surface behave as Brönsted acid sites and are thought to be catalytic centers of metal oxides $[35,36]$. Therefore, experiments were done to investigate the relationship among the $\gamma-\mathrm{Al}_{2} \mathrm{O}_{3}$ with different particle sizes and surface hydroxyl groups. The data in Table 1 show that there was a significant change in the concentration of surface hydroxyl groups with different particle sizes. The smaller the particle sizes, the greater the concentration of the surface hydroxyl groups. More surface hydroxyl groups mean that the catalyst surface can form more catalytic centers so that the catalytic efficiency had a certain improvement. According to the literature [37], the $\mathrm{pH}_{\mathrm{pzc}}$ of catalysts, which was closely related to their surface charge state and density, had a significant influence on organic pollutant removal in catalytic ozonation. The oxide surface gets protonated or deprotonated when the $\mathrm{pH}_{\mathrm{pzc}}$ is above or below the solution $\mathrm{pH}$. As shown in Table 1, the $\mathrm{pH}_{\mathrm{pzc}}$ of $\gamma-\mathrm{Al}_{2} \mathrm{O}_{3}$ increased with smaller particle size, which ranged from 7.22 to 7.73 and all exceeded the initial solution $\mathrm{pH}$ (sample A: $\mathrm{pH}=7.01$, sample $\mathrm{B}$ : $\mathrm{pH}=7.18$ ). In this case, most of the surface hydroxyl groups were in the protonated state. Thus, the effect of electrostatic attraction facilitated the adsorption of the organic pollutant on $\gamma-\mathrm{Al}_{2} \mathrm{O}_{3}$ resulting in improved removal efficiency of DOM.

Table 1. Refined physicochemical parameters for the commercial $\gamma$-alumina with different sizes.

\begin{tabular}{ccccc}
\hline sample & $\begin{array}{c}\text { BET Surface } \\
\text { Area }\left(\mathbf{m}^{\mathbf{2}} \cdot \mathbf{g}^{-\mathbf{1}}\right)\end{array}$ & $\begin{array}{c}\text { Pore Diameter } \\
\mathbf{( n m )}\end{array}$ & $\begin{array}{c}\text { Concentration of Surface } \\
\text { Hydroxyl Groups }\left(\mathbf{m m o l ~ g}^{-\mathbf{1}}\right)\end{array}$ & $\mathbf{p H}_{\mathbf{p z c}}$ \\
\hline$\gamma-\mathrm{Al}_{2} \mathrm{O}_{3}(0.1 \mathrm{~mm})$ & 322.43 & 5.08 & 1.83 & 7.73 \\
$\gamma-\mathrm{Al}_{2} \mathrm{O}_{3}(0.3 \mathrm{~mm})$ & 320.28 & 5.39 & 1.72 & 7.42 \\
$\gamma-\mathrm{Al}_{2} \mathrm{O}_{3}(0.5 \mathrm{~mm})$ & 306.93 & 5.56 & 1.56 & 7.23 \\
$\gamma-\mathrm{Al}_{2} \mathrm{O}_{3}(0.9 \mathrm{~mm})$ & 302.63 & 5.67 & 0.59 & 7.22 \\
\hline
\end{tabular}

The kinetic models of the removal of COD as fitted with the experimental data were presented in the plots. At present, the pseudo-first-order and pseudo-second-order equations were widely used in the study of ozone catalysis [38,39]. Therefore, the degradation curves of COD were fitted. It could be found that the correlation coefficients of the first-order kinetic model were higher than in the case of second-order kinetic model (the R-square of the first-order kinetic model was about 0.99 for sample $A$ and $B$, Figures $6 \mathrm{~B}$ and $7 \mathrm{~B}$, suggesting that the kinetics of the removal of COD by ozonation and ozonation catalysis could be more favorably described by the pseudo-first-order kinetic model. As the catalyst $\gamma-\mathrm{Al}_{2} \mathrm{O}_{3}$ particle size became smaller, the reaction rate constant increased gradually; $0.075 \mathrm{~min}^{-1}, 0.088 \mathrm{~min}^{-1}, 0.093 \mathrm{~min}^{-1}$ and $0.109 \mathrm{~min}^{-1}$, respectively (sample A); $0.085 \mathrm{~min}^{-1}, 0.093 \mathrm{~min}^{-1}, 0.101 \mathrm{~min}^{-1}$, and $0.116 \mathrm{~min}^{-1}$, respectively (sample A). As shown in Figure 8, linear correlation analysis was given between the first-order reaction rate and $\gamma-\mathrm{Al}_{2} \mathrm{O}_{3}$ particle size. Whether in the treatment of sample A or sample B, both showed a good linear correlation, which could imply that the decrease of the apparent particle size of the $\gamma-\mathrm{Al}_{2} \mathrm{O}_{3}$ could be helpful to the reaction rate; however, it might reach a maximum and, therefore, no longer increase the rate. Since the pseudo-first-order model could not identify the diffusion mechanism, the probability of intraparticle diffusion of DOM, the intraparticle diffusion model, was also used to analyze the kinetics of removal. From Figure 9, the correlation coefficients of the intraparticle diffusion model performed a good linear correlation, so it could be implied that the diffusion of DOM in the catalyst played another important role in the process of the catalytic reaction. 

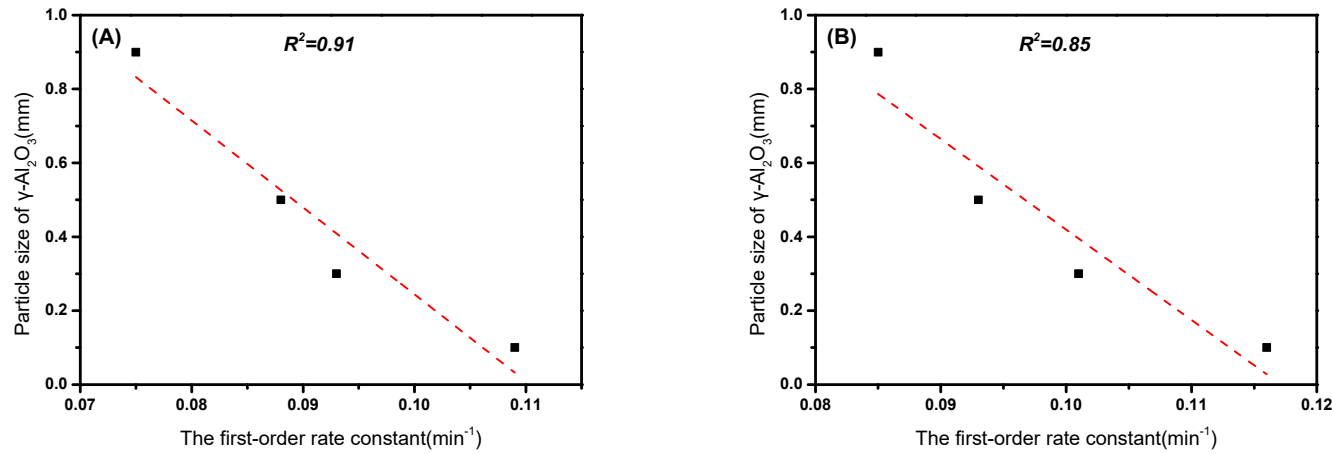

Figure 8. The linear correlation of the first-order rate constant and the particle size of $\gamma-\mathrm{Al}_{2} \mathrm{O}_{3}$ (sample A (A), sample B (B)).
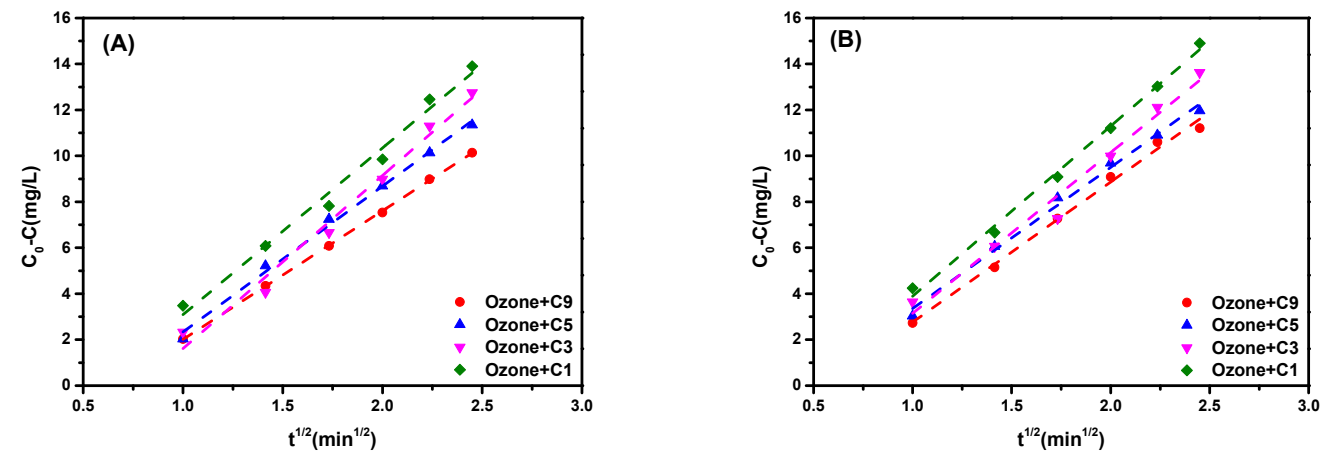

Figure 9. Plots of intraparticle diffusion model for COD removal of sample A (A) and sample B (B) by catalytic ozonation.

\subsection{Toxicity Study}

In order to assess the potential risks that the intermediates might have on the aquatic environment, the toxicity of the reaction solutions was evaluated by aquatic model species, P. phosphoreum. The filled symbols in Figure 10 show the observed acute inhibitory effects toward P. phosphoreum in terms of the relative bioluminescence inhibition in real samples collected after ozonation and $\gamma-\mathrm{Al}_{2} \mathrm{O}_{3} / \mathrm{O}_{3}$. From Figure 10, it could be found that both for the sample A or sample B, the water samples of toxicity had an obvious improvement after dealing with the ozone. The results and the report in the literature were consistent, after ozone treatment of water, higher toxicity would appear. The reason for this may be because the oxidation of ozone itself results in its inability to mineralize certain pollutants in water completely so that some intermediates are produced. Therefore, it had stronger toxicity compared with untreated water [40]. While, with the addition of the catalyst, the toxicity of two kinds of water samples showed an obvious decline compared with ozone alone, which should be caused by the introduction of catalysts. The refractory, poisonous and harmful parts of the materials were fully mineralized, resulting in the reduction of toxicity [41]. Then, it was interesting that the toxicity of the treatment water samples increased with the decrease of catalyst particle size. The cause of this result could be that the decrease of the catalyst particle size could produce more hydroxyl radicals so that some low toxic substances could be completely mineralized, while the substances that had not been decomposed at low hydroxyl radicals' contents were converted into the more toxic substances. 

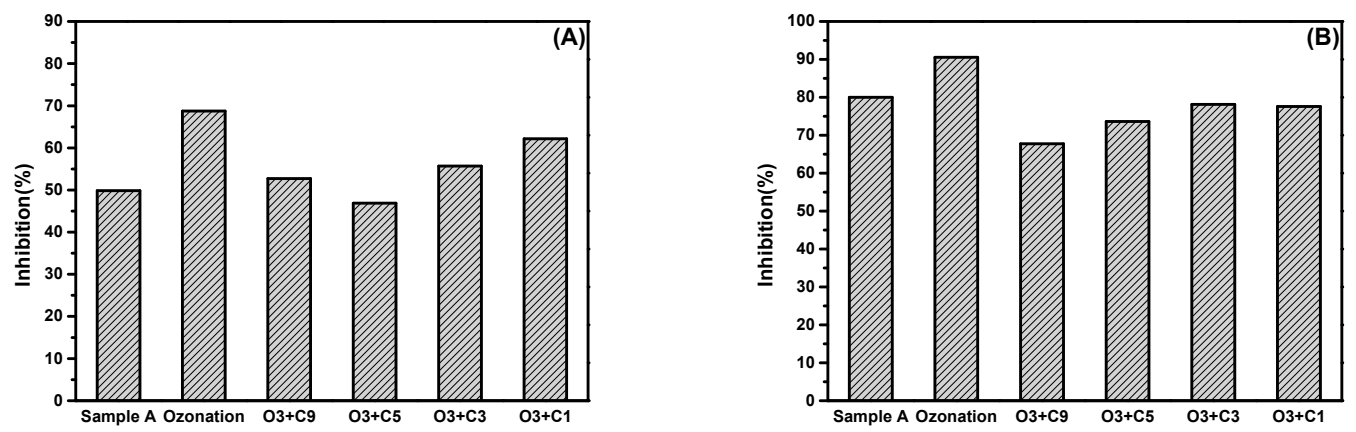

Figure 10. Changes in inhibition rates of ozonated and catalytic ozoned sample A (A) and sample B (B) to P. phosphoreum.

\section{Materials and Methods}

\subsection{Materials and Reagents}

Commercial $\gamma-\mathrm{Al}_{2} \mathrm{O}_{3}$ was purchased from Gongyi Yiyang Water Treatment Material Co., Ltd., Gongyi, China. Commercial $\gamma-\mathrm{Al}_{2} \mathrm{O}_{3}$ was smashed into different sizes of particles by mechanical breaking, and the particles were passed through screen mesh with different pore sizes so that they were divided into about $0.9 \mathrm{~mm}, 0.5 \mathrm{~mm}, 0.3 \mathrm{~mm}$, and $0.1 \mathrm{~mm}$, which were named C9, C5, C3, and C1, respectively. Other materials and reagents used in the test were of analytical grade.

\subsection{Catalyst Characterization}

The surface properties of the catalysts were determined by nitrogen adsorption and desorption experiments at $77 \mathrm{~K}$. The standard Brunauer-Emmett-Teller equation was employed to calculate the surface area of the catalysts. The pore sizes distribution was obtained from the desorption isotherms using the BJH (Barrett, Joyner, and Halenda) method (Autosorb-iQ2, Quantachrome, Boynton Beach, FL, USA).

The $\mathrm{pH}$ at zero charge $\left(\mathrm{pH}_{\mathrm{pzc}}\right)$ of the prepared catalysts was measured by the drift method as described [42]. In addition, the concentration of surface hydroxyl groups is described in the following; briefly, $0.3 \mathrm{~g}$ of catalyst powder was added to $50 \mathrm{~mL}$ of $\mathrm{NaOH}$ solutions in the concentration range 2-100 $\mathrm{mM}$ followed by shaking at $25^{\circ} \mathrm{C}$ for $>4 \mathrm{~h}$. The solution was passed through a membrane with a $0.22-\mu \mathrm{m}$ pore size, and the $\mathrm{NaOH}$ remaining in the supernatant was determined by titrating with a standard $\mathrm{HNO}_{3}$ solution. Because the acidic hydroxyl groups react with $\mathrm{NaOH}$, they can be readily quantified via calculation of the $\mathrm{NaOH}$ consumption. According to the principle of charge balance, the acidic and basic hydroxyl groups should be quantitatively equal. Hence, the total amount of the surface hydroxyl groups is twice that of the acidic groups.

\subsection{Raw Water Quality Indicators}

Conventional water quality indicators were shown in Table 2.

Table 2. Conventional raw water quality.

\begin{tabular}{ccccccc}
\hline Sample & COD(mg/L) & $\mathbf{U V}_{\mathbf{2 5 4}}$ & $\mathbf{p H}$ & $\begin{array}{c}\text { Total Nitrogen } \\
(\mathbf{m g} / \mathbf{L})\end{array}$ & $\begin{array}{c}\text { Total Phosphorus } \\
(\mathbf{m g} / \mathbf{L})\end{array}$ & $\begin{array}{c}\text { SUVA } \\
(\mathbf{L} / \mathbf{m} / \mathbf{m g})\end{array}$ \\
\hline Sample A & 29.0 & 0.220 & 7.01 & 13.7 & 0.17 & 2.03 \\
Sample B & 30.1 & 0.182 & 7.18 & 14.2 & 0.19 & 1.59 \\
\hline
\end{tabular}

Sample A was taken from Donggang sewage treatment plant (Wuxi, China) and sample B was taken from Wulongkou sewage treatment plant (Zhengzhou, China). 


\subsection{Ozonation and Catalytic Ozonation of Biological Effluents}

In a typical catalytic ozonation procedure, $0.5 \mathrm{~g}$ as-prepared catalyst was mixed with $500 \mathrm{~mL}$ biological effluents in a flask under magnetic stirring. The flowing rate of $\mathrm{O}_{3}$ during the ozonation process was kept at $0.5 \mathrm{~L} / \mathrm{min}$ and the concentration was $4.0 \mathrm{mg} / \mathrm{L}$. During the reaction process, $5 \mathrm{~mL}$ of solution was removed from the reactor for analysis in 1 min intervals. A similar experimental process was carried out by only ozone without catalysts.

\subsection{Water Sample Analysis}

UV absorbance at $254 \mathrm{~nm}\left(\mathrm{UV}_{254}\right)$ was measured on a Shimadzu UV-1800 spectrophotometer (Shimadzu, Kyoto, Japan) using a $1 \mathrm{~cm}$ quartz cell. Specific UV absorbance (SUVA) is defined as the $\mathrm{UV}_{254} \mathrm{~nm}$ normalized by DOC concentration and is a useful parameter for estimating the dissolved aromatic carbon content in water samples.

Excitation-emission matrix (EEM) fluorescence spectra were obtained on a Hitachi F-7000 fluorescence spectrophotometer (Hitachi, Kyoto, Japan) equipped with a $150 \mathrm{~W}$ Xe arc lamp at a PMT voltage of $700 \mathrm{~V}$. EEM analyses were conducted at a scan rate of $2400 \mathrm{~nm} / \mathrm{min}$ with sampling intervals of $5 \mathrm{~nm}$ and $1 \mathrm{~nm}$ in the excitation (Ex) and emission (Em) modes, respectively. The Ex and Em slit bandwidths were set at $5 \mathrm{~nm}$ with corrected spectra and shuttle control on. The scanning field was set from $220 \mathrm{~nm}$ to $400 \mathrm{~nm}$ for Ex and from $280 \mathrm{~nm}$ to $550 \mathrm{~nm}$ for Em. All the samples of raw MWEs were diluted to the same concentration of $2.0 \mathrm{mg} / \mathrm{L}$, and further diluted forty times before EEM determination. The dilution ratio of each resin-treated effluent was the same as the dilution ratio of its raw MWE. For accurate analysis of the EEM data, the Raman scattering effect was first removed by subtracting the IFE-corrected EEM of distilled water.

Gel-penetration chromatography (GPC) is a common instrument used to determine the molecular sizes distributions of DOM. A WATERS-515 (WATERS, USA) GPC with a WATERS gel column, a WATERS 2487 UV detector operating at $254 \mathrm{~nm}$ were used in this study.

The DOM fractionation method used in this study was derived from the procedure developed by Croue [43]. DOM was fractionated into hydrophobics, transphilics and hydrophilics using Amberlite XAD-8 and XAD-4 resins.

\subsection{Toxicity Assay}

The toxicities of the reaction solutions were assessed using both luminescent bacteria Photobacterium phosphoreum. The $\mathrm{pH}$ of the sample solutions was adjusted to 8.0 before test. The bioluminescence test was carried out according to the ISO standard method. After activation and incubation, the bacteria were exposed to the reaction solutions for $15 \mathrm{~min}$ at $20{ }^{\circ} \mathrm{C}$, and the bioluminescence was measured on a biological toxicity test instrument (DXY-3). Then, the inhibition rate against the blank control was calculated for each sample. To ensure the accuracy, all sample tests and control experiments were performed in triplicate.

\section{Conclusions}

In brief, this study investigated the effect of $\gamma-\mathrm{Al}_{2} \mathrm{O}_{3}$ with different particle sizes on DOM fractional removal by catalytic ozonation in municipal sewage advanced treatment. Firstly, ozonation substantially reduced the intensities of the fluorescence of the examined DOM fractions by EEM and the intensities were further reduced with the presence of the $\gamma-\mathrm{Al}_{2} \mathrm{O}_{3}$. While the decrease of the catalyst particle sizes contributed to the significant decrease of the fluorescence intensity, apart from in tryptophan. Secondly, the use of the catalyst in ozonation increased the removal of hydrophilic components and a decrease in the catalyst particle size increases the removal of hydrophilic components. In the end, through the characterization of the catalyst, it could be found that a specific surface area was not the key factor influencing the DOC fractional removal. The results implied that 
the surface hydroxyl groups of the catalyst $\gamma-\mathrm{Al}_{2} \mathrm{O}_{3}$ and the diffusion of DOM in the catalyst played important roles in the ozonation catalytic process for the removal of DOM.

Author Contributions: C.W. and C.S. initiated the concept; C.W. and C.S. designed and conceived of the experiments; C.W. and J.W. performed the experiments; C.W. and J.W. analyzed the data; C.W. and J.W. performed the characterizations, interpreted the data; A.L. contributed reagents/materials/analysis tools; C.W. drafted the manuscript, C.S. and A.L. corrected the manuscript. All authors read and approved the final manuscript.

Funding: This research received no external funding.

Acknowledgments: This work is supported of National Science Foundation of China $(51438008,51308283$ and 51290282) and the Foundation Research Funds for the Central Universities.

Conflicts of Interest: The authors declare no conflict of interest.

\section{References}

1. Gleick, P.H. A look at twenty-first century water resources development. Water Int. 2000, 25, 127-138. [CrossRef]

2. Nakada, N.; Shinohara, H.; Murata, A.; Kiri, K.; Managaki, S.; Sato, N.; Takada, H. Removal of selected pharmaceuticals and personal care products (PPCPs) and endocrine-disrupting chemicals (EDCs) during sand filtration and ozonation at a municipal sewage treatment plant. Water Res. 2007, 41, 4373-4382. [CrossRef] [PubMed]

3. Aiken, G.R.; Hsu-Kim, H.; Ryan, J.N. Influence of dissolved organic matter on the environmental fate of metals, nanoparticles, and colloids. Environ. Sci. Technol. 2011, 45, 3196-3201. [CrossRef] [PubMed]

4. Haitzer, M.; Höss, S.; Traunspurger, W.; Steinberg, C. Effects of dissolved organic matter (DOM) on the bioconcentration of organic chemicals in aquatic organisms-A review. Chemosphere 1998, 37, 1335-1362. [CrossRef]

5. Tang, H.L.; Chen, Y.-C.; Regan, J.M.; Xie, Y.F. Disinfection by-product formation potentials in wastewater effluents and their reductions in a wastewater treatment plant. J. Environ. Monit. 2012, 14, 1515-1522. [CrossRef] [PubMed]

6. Monteagudo, J.; Durán, A.; Martín, I.S.; García, S. Ultrasound-assisted homogeneous photocatalytic degradation of Reactive Blue 4 in aqueous solution. Appl. Catal. B 2014, 152, 59-67. [CrossRef]

7. Tang, F.; Hu, H.Y.; Sun, L.J.; Wu, Q.Y.; Jiang, Y.M.; Guan, Y.T.; Huang, J.J. Fouling of reverse osmosis membrane for municipal wastewater reclamation: Autopsy results from a full-scale plant. Desalination 2014, 349, 73-79. [CrossRef]

8. Cortés-Francisco, N.; Harir, M.; Lucio, M.; Ribera, G.; Martínez-Lladó, X.; Rovira, M.; Schmitt-Kopplin, P.; Hertkorn, N.; Caixach, J. High-field FT-ICR mass spectrometry and NMR spectroscopy to characterize DOM removal through a nanofiltration pilot plant. Water Res. 2014, 67, 154-165. [CrossRef] [PubMed]

9. Wang, J.; Li, H.; Li, A.; Shuang, C.; Zhou, Q. Dissolved organic matter removal by magnetic anion exchange resin and released ion elimination by electrolysis. Chem. Eng. J. 2014, 253, 237-242.

10. González, O.; Justo, A.; Bacardit, J.; Ferrero, E.; Malfeito, J.J.; Sans, C. Characterization and fate of effluent organic matter treated with $\mathrm{UV} / \mathrm{H}_{2} \mathrm{O}_{2}$ and ozonation. Chem. Eng. J. 2013, 226, 402-408.

11. Chu, W.; Gao, N.; Yin, D.; Deng, Y.; Templeton, M.R. Ozone-biological activated carbon integrated treatment for removal of precursors of halogenated nitrogenous disinfection by-products. Chemosphere 2012, 86, 1087-1091. [CrossRef] [PubMed]

12. Hollender, J.; Zimmermann, S.G.; Koepke, S.; Krauss, M.; McArdell, C.S.; Ort, C.; Singer, H.; von Gunten, U.; Siegrist, H. Elimination of organic micropollutants in a municipal wastewater treatment plant upgraded with a full-scale post-ozonation followed by sand filtration. Environ. Sci. Technol. 2009, 43, 7862-7869. [CrossRef] [PubMed]

13. Gharbani, P.; Khosravi, M.; Tabatabaii, S.; Zare, K.; Dastmalchi, S.; Mehrizad, A. Degradation of trace aqueous 4-chloro-2-nitrophenol occurring in pharmaceutical industrial wastewater by ozone. Int. J. Environ. Sci. Technol. 2010, 7, 377-384. [CrossRef]

14. Pocostales, J.P.; Sein, M.M.; Knolle, W.; von Sonntag, C.; Schmidt, T.C. Degradation of ozone-refractory organic phosphates in wastewater by ozone and ozone/hydrogen peroxide (peroxone): The role of ozone consumption by dissolved organic matter. Environ. Sci. Technol. 2010, 44, 8248-8253. [CrossRef] [PubMed] 
15. Volk, C.; Roche, P.; Joret, J.-C.; Paillard, H. Comparison of the effect of ozone, ozone-hydrogen peroxide system and catalytic ozone on the biodegradable organic matter of a fulvic acid solution. Water Res. 1997, 31, 650-656. [CrossRef]

16. Legube, B.; Leitner, N.K.V. Catalytic ozonation: A promising advanced oxidation technology for water treatment. Catal. Today 1999, 53, 61-72. [CrossRef]

17. Liu, J.; Wang, L.; Zhang, Q.; Wang, Q.; Xing, S. One-pot synthesis of cobalt-doped $\mathrm{Fe}_{3} \mathrm{O}_{4}$ with enhance catalytic activity for ozonation of 2, 4-D in aqueous solution. Chem. Lett. 2015, 44, 785-787. [CrossRef]

18. Sun, Q.Q.; Wang, Y.; Li, L.S.; Bing, J.S.; Wang, Y.X.; Yan, H.H. Mechanism for enhanced degradation of clofibric acid in aqueous by catalytic ozonation over MnOx/SBA-15. J. Hazard. Mater. 2015, 286, $276-284$. [CrossRef]

19. Huang, R.H.; Yan, H.H.; Li, L.S.; Deng, D.Y.; Shu, Y.H.; Zhang, Q.Y. Catalytic activity of Fe/SBA-15 for ozonation of dimethyl phthalate in aqueous solution. Appl. Catal. B 2011, 106, 264-271. [CrossRef]

20. Wang, Z.B.; Yin, G.-P.; Shi, P.-F. Effects of ozone treatment of carbon support on Pt-Ru/C catalysts performance for direct methanol fuel cell. Carbon 2006, 44, 133-140. [CrossRef]

21. Yuan, M.H.; Chang, C.Y.; Shie, J.L.; Chang, C.C.; Chen, J.H.; Tsai, W.T. Destruction of naphthalene via ozone-catalytic oxidation process over $\mathrm{Pt} / \mathrm{Al}_{2} \mathrm{O}_{3}$ catalyst. J. Hazard. Mater. 2010, 175, 809-815. [CrossRef] [PubMed]

22. Nakanishi, T.; Masuda, Y.; Koumoto, K. Deposition of $\gamma$-FeOOH, $\mathrm{Fe}_{3} \mathrm{O}_{4}$ and $\mathrm{Fe}$ on $\mathrm{Pd}$-catalyzed substrates. J. Cryst. Growth 2005, 284, 176-183. [CrossRef]

23. Maddila, S.; Dasireddy, V.D.B.C.; Oseghe, E.O.; Jonnalagadda, S.B. Ozone initiated dechlorination and degradation of trichlorophenol using Ce-Zr loaded metal oxides as catalysts. Appl. Catal. B 2013, 142-143, 129-141. [CrossRef]

24. Wang, J.; Zhou, Y.; Zhu, W.; He, X. Catalytic ozonation of dimethyl phthalate and chlorination disinfection by-product precursors over Ru/AC. J. Hazard. Mater. 2009, 166, 502-507. [CrossRef]

25. Gong, J.; Liu, Y.; Sun, $\mathrm{X} . \mathrm{O}_{3}$ and $\mathrm{UV} / \mathrm{O}_{3}$ oxidation of organic constituents of biotreated municipal wastewater. Water Res. 2008, 42, 1238-1244. [CrossRef] [PubMed]

26. Cooper, C.; Burch, R. An investigation of catalytic ozonation for the oxidation of halocarbons in drinking water preparation. Water Res. 1999, 33, 3695-3700. [CrossRef]

27. Pratarn, W.; Pornsiri, T.; Thanit, S.; Tawatchai, C.; Wiwut, T. Adsorption and ozonation kinetic model for phenolic wastewater treatment. Chin. J. Chem. Eng. 2011, 19, 76-82. [CrossRef]

28. Zhang, T.; Lu, J.; Ma, J.; Qiang, Z. Fluorescence spectroscopic characterization of DOM fractions isolated from a filtered river water after ozonation and catalytic ozonation. Chemosphere 2008, 71, 911-921. [CrossRef]

29. Imai, A.; Fukushima, T.; Matsushige, K.; Kim, Y.H.; Choi, K. Characterization of dissolved organic matter in effluents from wastewater treatment plants. Water Res. 2002, 36, 859-870. [CrossRef]

30. Labanowski, J.; Feuillade, G. Dissolved organic matter: Precautions for the study of hydrophilic substances using XAD resins. Water Res. 2011, 45, 315-327. [CrossRef]

31. Gago-Ferrero, P.; Demeestere, K.; Díaz-Cruz, M.S.; Barceló, D. Ozonation and peroxone oxidation of benzophenone-3 in water: Effect of operational parameters and identification of intermediate products. Sci. Total Environ. 2013, 443, 209-217. [CrossRef] [PubMed]

32. Asghar, A.; Raman, A.A.A.; Daud, W.M.A.W. Advanced oxidation processes for in-situ production of hydrogen peroxide/hydroxyl radical for textile wastewater treatment: A review. J. Clean. Prod. 2015, 87, 826-838. [CrossRef]

33. Zhao, L.; Sun, Z.; Ma, J. Novel relationship between hydroxyl radical initiation and surface group of ceramic honeycomb supported metals for the catalytic ozonation of nitrobenzene in aqueous solution. Environ. Sci. Technol. 2009, 43, 4157-4163. [CrossRef] [PubMed]

34. Joseph, Y.; Ranke, W.; Weiss, W. Water on $\mathrm{FeO}$ (111) and $\mathrm{Fe}_{3} \mathrm{O}_{4}$ (111): Adsorption behavior on different surface terminations. J. Phys. Chem. B 2000, 104, 3224-3236. [CrossRef]

35. Yang, L.; Hu, C.; Nie, Y.; Qu, J. Catalytic ozonation of selected pharmaceuticals over mesoporous alumina-supported manganese oxide. Environ. Sci. Technol. 2009, 43, 2525-2529. [CrossRef] [PubMed]

36. Kasprzyk-Hordern, B.; Ziółek, M.; Nawrocki, J. Catalytic ozonation and methods of enhancing molecular ozone reactions in water treatment. Appl. Catal. B 2003, 46, 639-669. [CrossRef]

37. Andreozzi, R.; Insola, A.; Caprio, V.; Marotta, R.; Tufano, V. The use of manganese dioxide as a heterogeneous catalyst for oxalic acid ozonation in aqueous solution. Appl. Catal. A 1996, 138, 75-81. [CrossRef] 
38. Oputu, O.; Chowdhury, M.; Nyamayaro, K.; Fatoki, O.; Fester, V. Catalytic activities of ultra-small $\beta$-FeOOH nanorods in ozonation of 4-chlorophenol. J. Environ. Sci. 2015, 35, 83-90. [CrossRef] [PubMed]

39. Matheswaran, M.; Balaji, S.; Chung, S.J.; Moon, I.S. Studies on cerium oxidation in catalytic ozonation process: A novel approach for organic mineralization. Catal. Commun. 2007, 8, 1497-1501. [CrossRef]

40. Kuang, J.; Huang, J.; Wang, B.; Cao, Q.; Deng, S.; Yu, G. Ozonation of trimethoprim in aqueous solution: Identification of reaction products and their toxicity. Water Res. 2013, 47, 2863-2872. [CrossRef] [PubMed]

41. Guo, Y.; Xu, B.; Qi, F. A novel ceramic membrane coated with $\mathrm{MnO}_{2}-\mathrm{Co}_{3} \mathrm{O}_{4}$ nanoparticles catalytic ozonation for benzophenone-3 degradation in aqueous solution: Fabrication, characterization and performance. Chem. Eng. J. 2016, 287, 381-389. [CrossRef]

42. Tangsir, S.; Hafshejani, L.D.; Lähde, A.; Maljanen, M.; Hooshmand, A.; Naseri, A.A.; Moazed, H.; Jokiniemi, J.; Bhatnagar, A. Water defluoridation using $\mathrm{Al}_{2} \mathrm{O}_{3}$ nanoparticles synthesized by flame spray pyrolysis (FSP) method. Chem. Eng. J. 2016, 288, 198-206. [CrossRef]

43. Croué, J.P.; Benedetti, M.; Violleau, D.; Leenheer, J. Characterization and copper binding of humic and nonhumic organic matter isolated from the South Platte River: Evidence for the presence of nitrogenous binding site. Environ. Sci. Technol. 2003, 37, 328-336. [CrossRef] [PubMed]

(C) 2018 by the authors. Licensee MDPI, Basel, Switzerland. This article is an open access article distributed under the terms and conditions of the Creative Commons Attribution (CC BY) license (http:/ / creativecommons.org/licenses/by/4.0/). 